\title{
19. PRELIMINARY RESULTS OF PETROGRAPHIC AND ELECTRON-SPIN-RESONANCE STUDIES OF ORGANIC MATTER FROM DEEP SEA DRILLING PROJECT SITES 370 AND 416
}

\author{
A. Boutefeu and P. Leplat, Labofina S.A. (Centre de Recherches du Groupe Pétrofina), Brussels, Belgium \\ and \\ Y. Somers, Institut National des Industries Extractives, Liège, Belgium
}

\begin{abstract}
Petrographic observations confirm the continental origin of the organic matter and the presence of reworked, altered organic material in the sediments from DSDP Sites 370 and 416 . The reflectance of the primary vitrinite-huminite population establishes that these samples are in the mature stage of evolution. The very low organic-carbon content of these samples makes ESR interpretation particularly difficult.
\end{abstract}

\section{INTRODUCTION}

This study was carried out to supplement organicgeochemistry information obtained by pyrolysis study of samples from DSDP Sites 370 and 416 (Boutefeu, this volume).

The reflectance of vitrinite-huminite particles is used to determine the degree of maturation of organic matter. The type of organic matter is determined by visual examination in normal reflected light and in transmitted light, and by fluorescence. In the electron-spin-resonance (ESR) technique, measurements of the $g$ value and the intensity of the signal allow determination of the degree of maturation of organic matter, when the petrographic type of organic matter is known (Libert et al., 1976). Results of analyses are presented in Table 1 and Figures 1, 2, and 3. Some petrographic types of organic matter are illustrated in Plate 1.

\section{ANALYTICAL METHODS}

\section{Microscopic Analysis}

Two kinds of separation were made. The first was a manual separation of macroscopic organic particles under a binocular microscope. The isolated particles were embedded in a synthetic resin and then polished. This preparation is studied only in reflected light. The second was separation of the dispersed organic matter in crushed samples by centrifugation in a heavy liquid (specific gravity 2.0). The organic-matter concentrate is then firmly fixed on a Plexiglas slide and polished (Cerchar method). This preparation can be examined either in reflected or transmitted light.

Huminite-vitrinite reflectance was measured with a Leitz-Ortholux reflecting microscope equipped with a stabilized light source and a photomultiplier (type EMI 6094). Our methods followed international standards (Internat. Committee for Coal Petrology, 1975). We used monochromatic light $(546 \mathrm{~nm})$; mean reflectance (in non-polarized light) was measured over an area about $4 \mu \mathrm{m}$ in diameter, with a $\times 60$ oil-immersion objective.

\section{ESR Measurements}

We used a Varian model E112-9-5 GHz ESR spectrometer. Standard ESR tubes were filled with decarbonated $\left(10 \% \mathrm{HCl}\right.$ at $60^{\circ} \mathrm{C}$ for 1 hour, washed with hot distilled water), ground samples and tightly stoppered. To avoid errors and to allow comparisons among samples, all spectra were recorded under identical conditions, using the dual-cavity technique at room temperature. Both the sample and a Varian standard pitch were scanned with a 200 -Gauss sweep range, at room temperature; the modulation frequency was 100 $\mathrm{kHz}$, and the microwave frequency was $9.512 \mathrm{GHz}$.

\section{Pyrolysis Methods}

We utilized two methods. The first is an IFP-Fina process which has been described by Espitalié et al. (1977). Data obtained by this method are given in other chapters of this volume (Boutefeu; Deroo et al.). The second method involved an oven directly connected to a differential dual-flame ionization detector. The oven temperature was raised from the ambient temperature to $950^{\circ} \mathrm{C}$ at $6^{\circ} \mathrm{C} / \mathrm{min}$. This second technique, which is slower than the first, gives more-accurate results, especially at higher temperatures (Boutefeu, in prep.).

The parameters evaluated by pyrolysis include $T_{M}$, which is the temperature at peak intensity of pyrolysis of insoluble organic matter, and the hydrogen index (HI), which is the yield of hydrocarbons produced during pyrolysis, expressed in milligrams of hydrocarbon per gram of organic carbon.

\section{ANALYTICAL RESULTS}

\section{Petrographic Results}

Coaly particles can be identified by microscopic examination of polished surfaces in reflected light. On the basis of morphology and reflectance, particles are clas- 
TABLE 1

Analy tical Data on Organic Matter, Sites 370 and 416

\begin{tabular}{|c|c|c|c|c|c|c|c|c|c|c|c|}
\hline \multirow{3}{*}{$\begin{array}{c}\text { Sample } \\
\text { (Interval in } \mathrm{cm} \text { ) }\end{array}$} & \multirow{3}{*}{$\begin{array}{l}\text { Sub-Bottom } \\
\text { Depth } \\
\text { (m) }\end{array}$} & \multicolumn{3}{|c|}{ Reflectance } & \multicolumn{4}{|c|}{ Visual Analysis ${ }^{\mathrm{a}}$} & \multicolumn{2}{|c|}{ Pyrolysis Data } & \multirow[b]{3}{*}{$\mathrm{C}_{\text {tot }} \mathrm{e}^{\mathrm{n}}$} \\
\hline & & $R_{o}$ & Number of & & \multicolumn{3}{|c|}{ Type of OM } & \multirow[b]{2}{*}{ Fluorescence ${ }^{b}$} & \multirow{2}{*}{$\begin{array}{l}\text { Hydrogen } \\
\text { Index }\end{array}$} & \multirow{2}{*}{$\begin{array}{l}T_{M}^{\mathrm{d}} \\
\left({ }^{\circ} \mathrm{C}\right)\end{array}$} & \\
\hline & & $(\%)$ & Observations & $\sigma$ & $\mathrm{H}$ & L & $\mathrm{R}$ & & & & \\
\hline $416 \mathrm{~A}-2-3,109-150$ & 302.2 & 0.21 & 10 & 0.03 & - & - & & $\bullet$ & 118 & 411 & 0.97 \\
\hline $370-8-2,66-70$ & 466.2 & 0.19 & 47 & 0.03 & - & - & - & + & 149 & 416 & 0.91 \\
\hline $16-2,42-45$ & 608.4 & 0.29 & 44 & 0.09 & - & + & - & + & 534 & 429 & 5.61 \\
\hline $26-3,22-25$ & 733.2 & 0.16 & 23 & 0.07 & $\bullet$ & - & $\bullet$ & & 71 & 422 & 0.66 \\
\hline $32-3,82-86$ & 838.3 & 0.19 & 45 & 0.05 & $\bullet$ & + & - & + & 431 & 425 & \\
\hline $33, \mathrm{CC}$ & 854.0 & 0.20 & 37 & 0.05 & - & - & - & - & 137 & 427 & 1.29 \\
\hline $41-2,25-29$ & 988.3 & 0.21 & 48 & 0.03 & + & - & & & 108 & 423 & \\
\hline $44-1,6-10$ & 1043.6 & 0.25 & 27 & 0.05 & + & - & - & & 130 & 427 & 0.90 \\
\hline $46-5,57-60$ & 1088.1 & 0.35 & 50 & 0.05 & + & - & & & 60 & 428 & \\
\hline $49-1,44-46$ & 1138.9 & 0.29 & 46 & 0.06 & + & $\bullet$ & $\bullet$ & & 77 & 427 & \\
\hline $416 \mathrm{~A}-14, \mathrm{CC}, 30-33$ & 1232.7 & 0.33 & 50 & 0.04 & + & - & & & 76 & 427 & 0.50 \\
\hline $22-4,0-3$ & 1304.0 & 0.42 & 97 & 0.06 & + & - & - & & 88 & 424 & \\
\hline $23-2,101-103$ & 1311.6 & 0.36 & 50 & 0.06 & + & - & & & 67 & 432 & 0.59 \\
\hline $24-2,58-59$ & 1320.7 & 0.27 & 50 & 0.04 & + & & & & 296 & 409 & \\
\hline $24-2,64-65$ & 1320.7 & 0.26 & 50 & 0.04 & + & & & & 83 & 430 & \\
\hline $26-1,32-34$ & 1337.5 & 0.36 & 76 & 0.04 & + & - & $\bullet$ & & 118 & 428 & 1.23 \\
\hline $30-2,68-70$ & 1377.4 & 0.38 & 50 & 0.05 & + & - & - & & 30 & 430 & \\
\hline $32-3,11-15$ & 1397.2 & 0.42 & 92 & 0.05 & + & - & $\bullet$ & & 63 & 422 & \\
\hline $38-2,33-35$ & 1446.8 & 0.47 & 49 & 0.05 & + & - & - & & 63 & 434 & \\
\hline $48-3,55-59$ & 1533.1 & 0.54 & 86 & 0.09 & + & $\bullet$ & $\bullet$ & & 32 & 432 & \\
\hline $51-2,80-84$ & 1560.4 & 0.47 & 49 & 0.07 & + & - & - & & 75 & 432 & \\
\hline $52-1,71-75$ & 1568.1 & 0.37 & 89 & 0.09 & + & - & - & & 99 & 431 & \\
\hline $53-2,91-94$ & 1579.2 & 0.30 & 25 & 0.07 & + & $\bullet$ & $\bullet$ & & 15 & 423 & \\
\hline $57-1,83-88$ & 1615.3 & 0.52 & 47 & 0.09 & + & - & $\bullet$ & & 38 & 429 & \\
\hline
\end{tabular}

${ }_{\mathrm{b}}^{\mathrm{a}} \mathrm{H}=$ humic type; $\mathrm{L}=$ liptinic type $\mathrm{R}=$ reworked - = rare $; \bullet=$ common; + = abundant.

$\mathrm{b}_{\mathrm{Qualita}}$ tive fluorescence under blue-light irradiation.

c mg HC/g C org.

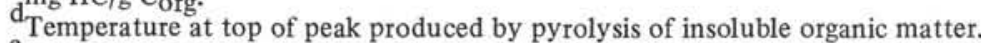

$\mathrm{e}_{\mathrm{Per}}$ cent $\mathrm{C}_{\text {org }}$ in decarbonated samples.

sified, in order of increasing reflectance, as liptinite-exinite, huminite-vitrinite, or inertinite.

The commonest constituents are huminite (corresponding to the lignite stage of coal evolution). Huminite consists of humic substances which primarily orginate from lignin and cellulose; it indicates a continental origin. Huminite is present as cell walls in process of gelification (texto-ulminite [Plate 1, Figure 4]; euulminite [Plate 1, Figure 2]); as a homogeneous, amorphous gel (porigelinite, levigelinite [Plate 1, Figures 5-7]); or as cellular inclusions (corpohuminite).

The hand-picked organic matter (Samples 416A-23-2, 101-103 cm, 416A-24-2, 58-59 cm, 416A-24-2, 64-65 $\mathrm{cm}, 416 \mathrm{~A}-26-1,32-34 \mathrm{~cm}$, and $416 \mathrm{~A}-51-2,80-82 \mathrm{~cm}$ ) belongs solely to the huminite group and consists essentially of texto-ulminite and eu-ulminite. Inertinite is rare and occurs only as minute splinters (Plate 1, Figure 6). Most samples also contain a variable proportion of reworked vitrinite. Some reworked microspores (Carboniferous, for instance) are present. Liptinite is present in the samples, most frequently in small quantities. In general, it is visible only in fluorescent or transmitted light (Plate 1, Figure 3) and not in reflected light, because of the low maturity of the dispersed organic matter.

Investigation under fluorescent light (Plate 1, Figure $3 b)$ was purely qualitative; it made possible identification of liptinite-exinite constituents, i.e., those which are $\mathrm{H}$-rich, of continental origin (resins, cuticles, spores), or of aquatic origin (algae). The identified constituents were mainly spores, cuticles, resin particles, and minute spheres (5-15 $\mu \mathrm{m}$ in diameter) with a very intense lemon-yellow fluorescence, which resemble the algae of the genus Nostocopsis (Schizophyceae) described by Mädler (1963). Other algae, with an intense yellow to greenish fluorescence, were encountered sporadically. In some samples, mainly $370-8-2,66-70 \mathrm{~cm}$, $370-16-2,42-45 \mathrm{~cm}$ and $370-32-3,82-86 \mathrm{~cm}$ the liptinite group predominates. Elsewhere, this group occurs regularly, but always in small quantities.

Examination in transmitted light confirmed the observations made in reflected light and made possible identification of the type of kerogen. We were able to identify two types: one type of the ligno-humite series, consisting mainly of ligneous particles (humic kerogen; Plate 1, Figures 1 and 2) and one of the liptobiolite series, consisting mainly of exines (liptinic kerogen; Plate 1, Figure 3) (Combaz, 1975). The first type dominates the whole series from Sample 370-41-2, 25-29 cm to the bottom of the hole. The second type occurs only in the upper part of the sequence, mainly in Samples $370-16-2,42-45 \mathrm{~cm}$ and $370-32-3,82-86 \mathrm{~cm}$. In the upper part of the sequence, mixed types are also found (a mixture of ligneous and liptinitic matter, Samples $370-8-2,66-70 \mathrm{~cm}$ and $370-33, \mathrm{CC})$. 


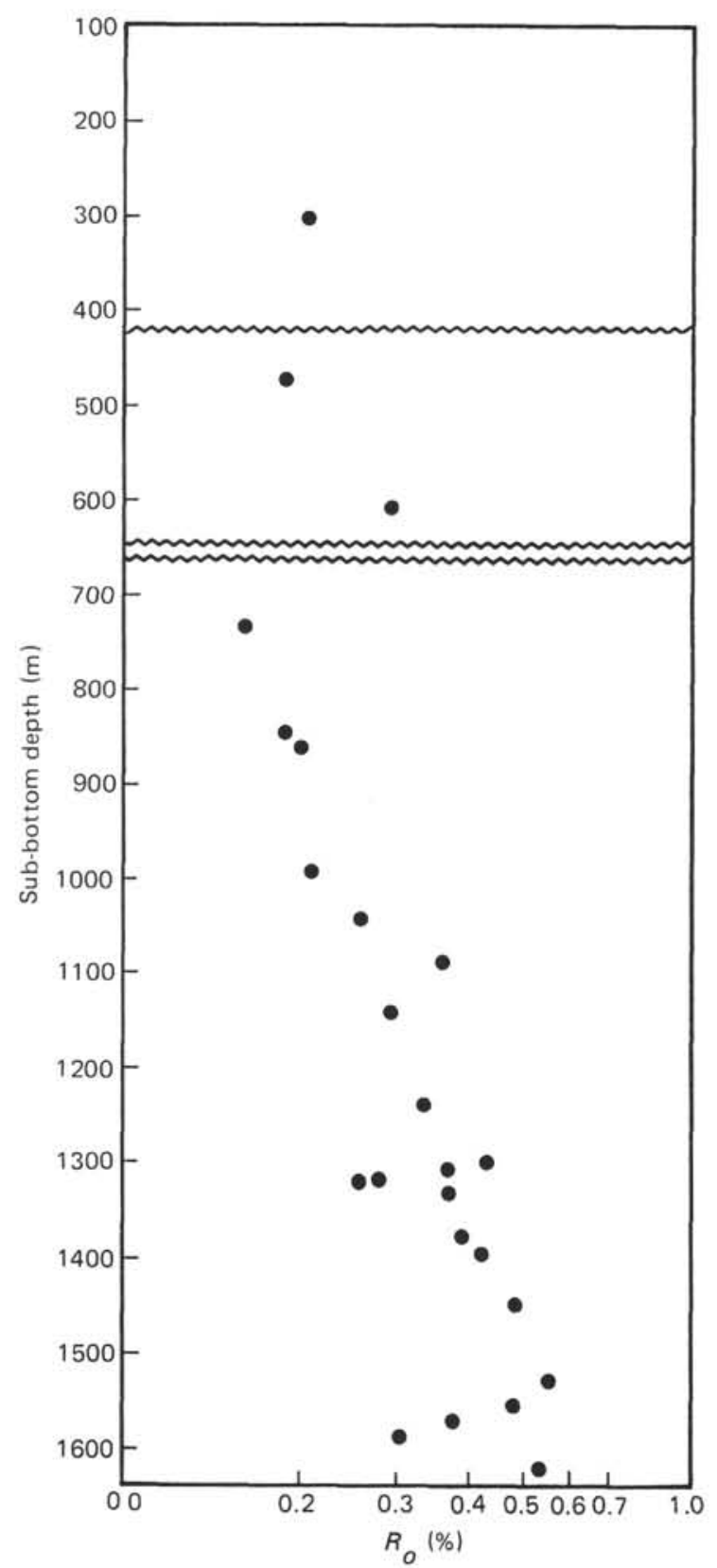

Figure 1. Vertical distribution of reflectance values (wavy lines indicate hiatuses).

According to their chemical composition, the observed constituent types can be placed on the evolution diagram established by Van Krevelen (1961) for coal macerals, and they can be compared with the kerogenevolution paths on the diagram of Tissot et al. (1974). The ligno-humic type resembles kerogen of type III, and the liptobiolite type resembles kerogen of type II. On the other hand, we did not find any amorphous or sapropelic types, considered as the best indication of potential for liquid hydrocarbons (evolution path I of Tissot et al., 1974).

The results of this qualitative study with the data from the reflected light, transmitted light and fluores-
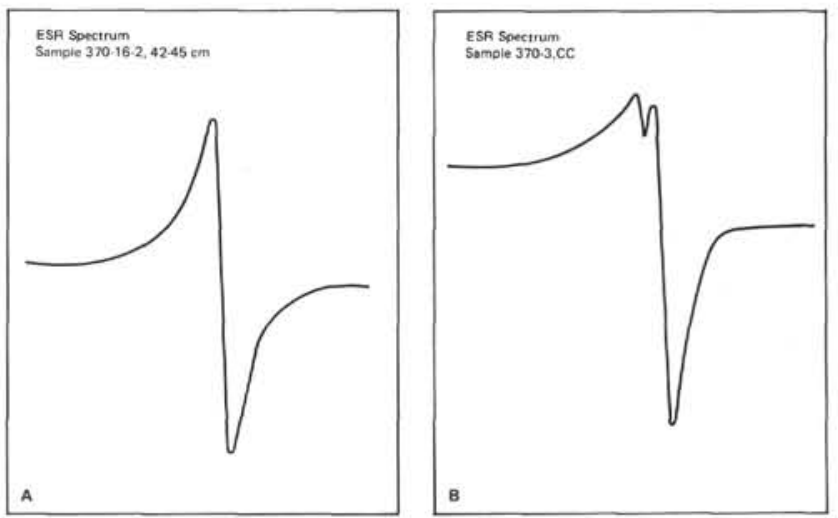

Figure 2. ESR spectra of decarbonated samples. (A) "Normal" absorption line. (B) Asymmetric spectrum, showing two absorption peaks.
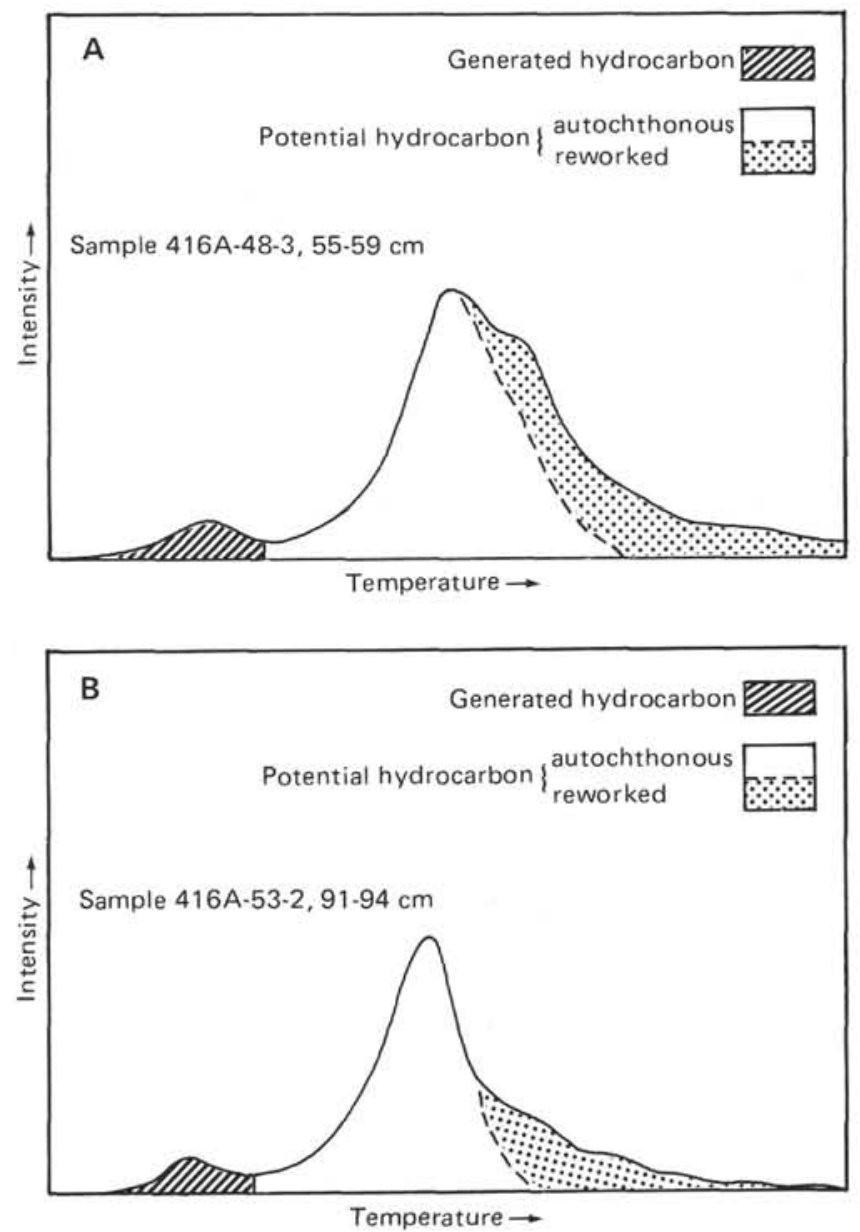

Figure 3. Pyrogram of untreated samples, obtained by pyrolysis up to $950^{\circ} \mathrm{C}$ at $6^{\circ} \mathrm{C} / \mathrm{min}$. (A) Sample containing some reworked organic matter, $\mathrm{R}_{\mathrm{o}}$ ranging from 0.85 to $1.68 \mathrm{per}$ cent. For the non-reworked population, $\mathrm{R}_{\mathrm{o}}$ is 0.54 per cent. (B) Sample containing some reworked organic matter, $\mathrm{R}_{\mathrm{o}}$ ranging from 0.58 to 2.38 per cent. For the non-reworked population, $\mathrm{R}_{\mathrm{o}}$ is 0.30 per cent. 
cent light examination are set out in Table 1. Of the fluorescent results, only the most important data are tabulated, and not the isolated fluorescence of spores, cuticles, and resins found commonly in all samples of dominantly ligneous type.

\section{Maturation Determinations}

The stage of diagenetic development, or maturation, was determined by measuring the reflectance $\left(R_{o}\right)$ of the huminite-vitrinite particles. Measurements were possible only below a sub-bottom depth of 300 meters (Sample $416 \mathrm{~A}-2-3,109-150 \mathrm{~cm}$ ); the results are shown in Table 1 and Figure 1 . The observed values of $R_{0}$ ranged from 0.21 per cent $(300 \mathrm{~m})$ to 0.52 per cent $(1615 \mathrm{~m})$, which corresponds to coal-rank stages ranging from the peat-lignite transition to the transition from sub-bituminous to high-volatile bituminous coal. These results show that the investigated sediments are immature and have just reached the beginning of the zone of oil formation $\left(R_{o} \simeq 0.50 \%\right)$.

\section{Electron-Spin Resonance}

Because the samples were not large enough, we worked on decarbonated samples and not on kerogen. This may explain why (if we except samples which exhibit normal isotropic spectra, as in Figure 2A) some samples exhibit asymmetric spectra with two absorption peaks (Figure 2B). This led us to conflicting interpretations. The organic-carbon contents of decarbonated samples are low (Table 1), and the inorganic matrix can be held responsible for these spectra, which seem at first glance comparable with these found for ball clay by Hall et al. (1974). Those authors have shown for clays asymmetric spectra at $g=2.003$, which is a $g$ value generally found for organic matter (Baker et al., 1978).

Because there is still doubt about the origins of these signals, we are waiting for results of complementary work on kerogen of composite samples from Sites $\mathbf{3 7 0}$ and 416 before presenting results.

\section{DISCUSSION AND COMPARISON WITH PYROLYSIS DATA}

Based on visual analysis, the organic matter of Holes $416 \mathrm{~A}$ and 370 can be divided into two main groups. The first, from the top of the sequence down to 900 meters, is characterized by fluorescent organic matter consisting of a mixture of liptinic and humic materials associated with grayish-olive marl, marlstone, mudstone, siltstone, and claystone. As Table 1 shows, these samples have the higher hydrogen indexes. According to their petrographic composition and to their comparison with the evolution diagram of Van Krevelen (1961) and the kerogen-evolution paths of Tissot et al. (1974), these samples could be placed between the evolution paths of type II and type III kerogens. With the exception of a few samples, hydrogen indexes are lower than 150, and the material belongs on this basis to type III kerogen. One possible explanation of this anomaly is the presence of reworked, altered organic matter which lowers the hydrogen index.
From 900 meters to the bottom of the section, organic matter is mainly humic, with a small liptinic contribution. Here again, the visual analysis shows the presence of reworked, altered organic matter. This explains the low values of hydrogen indexes and the fact that most of the samples plot below the evolution path of type III organic matter on the basis of pyrolysis (Boutefeu; Deroo et al.; this volume). This presence of reworked organic matter is obvious on pyrograms for samples which have very low hydrogen indexes (Figure 3 ), and it accords well with sample populations having higher reflectances. The weak contribution of liptinic type organic material from 900 meters to the bottom of the sequence is not surprising, considering that terrigenous turbidites are the main type of sediment (Site 416 report, this volume).

The reflectance values $\left(R_{o}\right)$ of these samples are below 0.5 per cent, except for two samples. The immature stage of evolution is also shown by the $T_{M}$ pyrolysis values; they are below 435 to $440^{\circ} \mathrm{C}$, which marks the beginning of the principal zone of oil formation.

\section{CONCLUSIONS}

Visual analysis shows that the main type of organic matter is humic, with a liptinic contribution which decreases down the sequence. This agrees fairly well with pyrolysis data, which show a similar decrease in the hydrogen index. Some reworked, altered material diminishes the overall quality of the organic matter and explains why the hydrogen indexes are so low, even in the upper part of the sequence, where the liptinic type is more common. Both pyrolysis and reflectance data indicate an immature stage of evolution for these samples. The influence of the inorganic matrix can not be excluded from the ESR results, and before drawing any conclusion on this point, we prefer to continue our studies.

\section{ACKNOWLEDGMENTS}

The authors thank Prof. B. Alpern (Université d'Orléans, France) and Dr. A. Marchand (Centre de Recherches Paul Pascal, Talence, France) for their review of the paper.

\section{REFERENCES}

Baker, E. W., Huang, W. Y., Rankin, J. G., Castaño, J. R., Guinn, J. R., and Fuer, A. M., 1977. Electron paramagnetic resonance study of thermal alteration of kerogen in deep sea sediments by basaltic sill intrusion. In Lancelot, Y., Seibold, E., et al., Init. Repts. DSDP, 41: Washington (U.S. Govt. Printing Office), pp. 839-848.

Combaz, A., 1975. Essai de classification des roches carbonées et des constituants organiques des roches sédimentaires. In Alpern, B. (Ed.), Pétrographie Organique et Potentiel Pétrolier: Paris (CNRS), pp. 93-101.

Espitalié, J., Laporte, J. L., Madec, M., Marquis, F., Leplat, P., Paulet, J., and Boutefeu, A., 1977. Méthode rapide de caractérisation des roches mères, de leur potential pétrolier et de leur degré d'évolution. Rev. Inst. Fr. Pétrole, 32, 23-42.

Hall, P. L., Angel, B. R., and Braven, J., 1974. Electron spin resonance and related studies of lignite and ball clay from south Devon, England. Chemical Geol., 13, 97-113. 
International Committee for Coal Petrology, 1975. International Handbook of Coal Petrography (2nd suppl. to 2nd ed.): Paris (CNRS).

Libert, P., Marchand, A., and Achard, M. F., 1976. Etude physico-chimique des résidus de pyrolyse de la sporopollénine. Geochim. Cosmochim., 40, 143-148.
Mädler, K., 1963. Die Figurierten organischen Bestandteile der Posidonienschiefer. Beih. geol. jahrb., 58, 287-406.

Tissot, B., Durand, B., Espitalié, J., and Combaz, A., 1974. Influence of nature and diagenesis of organic matter in formation of petroleum. Bull. Am. Assoc. Petrol. Geol., 58, 499-506.

Van Krevelen, D. W., 1961. Coal: Amsterdam (Elsevier). 


\section{PLATE 1}

All figures $\times 300$, oil immersion. Organic concentrate, polished thin section, except Figure 4.

Figure 1 Humic kerogen. Ligneous particles dominant, in the center of the picture a liptinic particle. Sample 416A-57-1, 83-88; depth 1615 meters. Transmitted light.

Figure 2 Humic kerogen. Relatively large ligneous (euulminite) particle, with pyrite. Sample 416A-14, CC, 30-33; depth 1233 meters. 2a, transmitted light; $2 \mathrm{~b}$, reflected light.

Figure 3 Liptinic kerogen. Exines dominant, some nonfluorescent ligneous particles. Sample 370-16-2, 42-45; depth 608 meters. 3a, transmitted light; 3b, fluorescent light (blue light irradiation).

Figure 4 Texto-ulminite. Sample 416A-23-2, 101-103; depth 1312 meters. Hand-picked organic material, polished block. Reflected light.

Figure 5 Levigelinite. Sample 416A-14, CC, 30-33; depth 1233 meters. Reflected light.

Figure $6 \quad$ Ulminite and gelinite particles, and some very small fusinite particles. Sample 370-46-5, 57-60; depth 1088 meters. Reflected light. 
PLATE 1
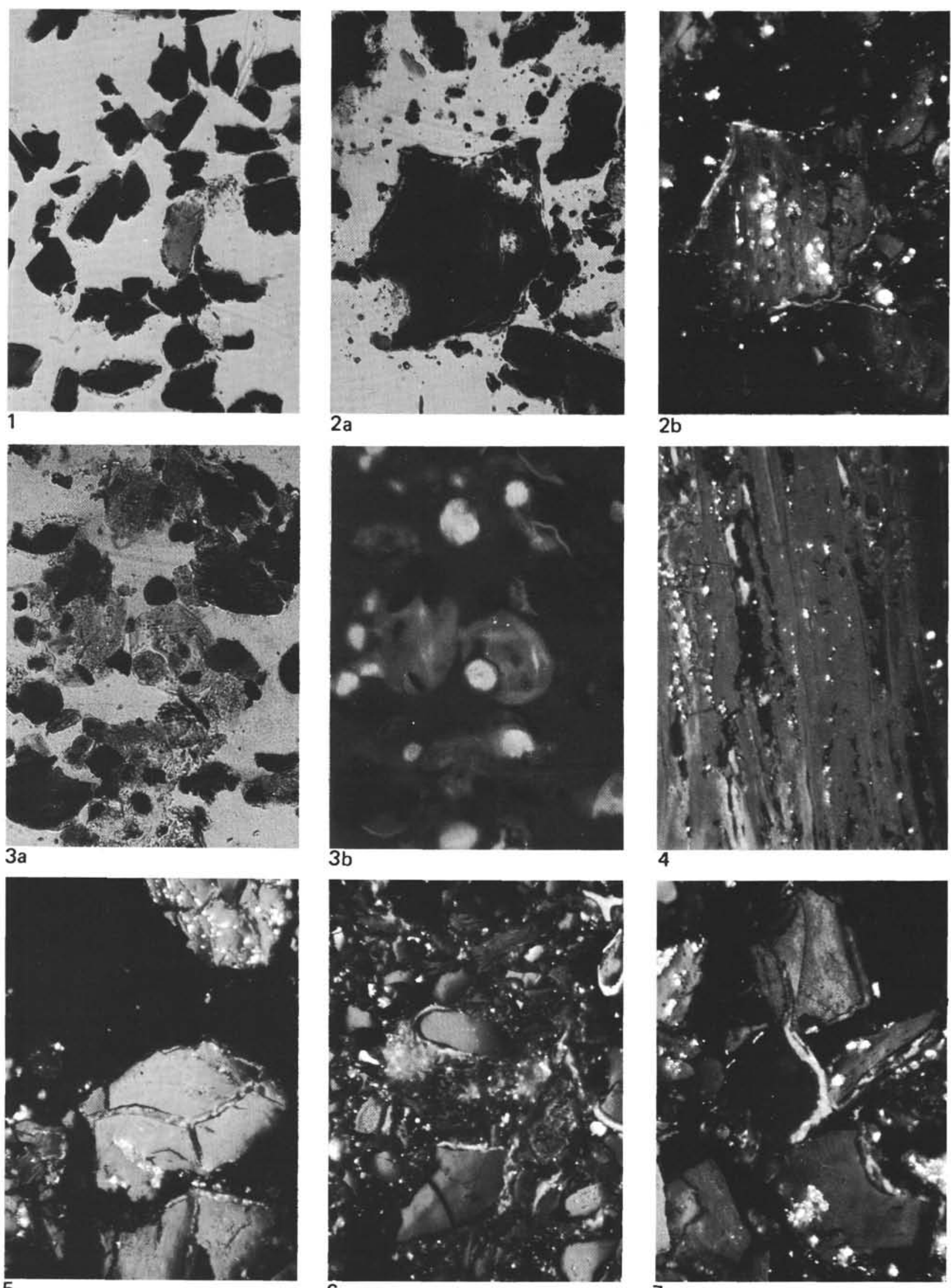

\section{$3 b$}

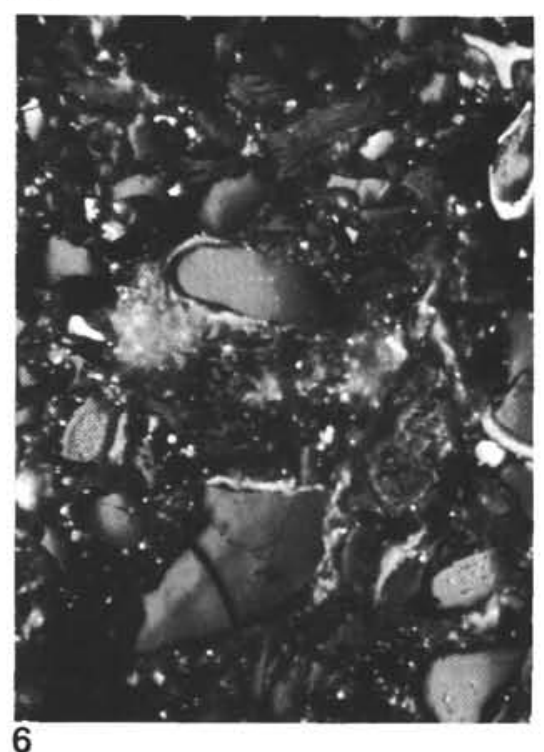

$2 b$
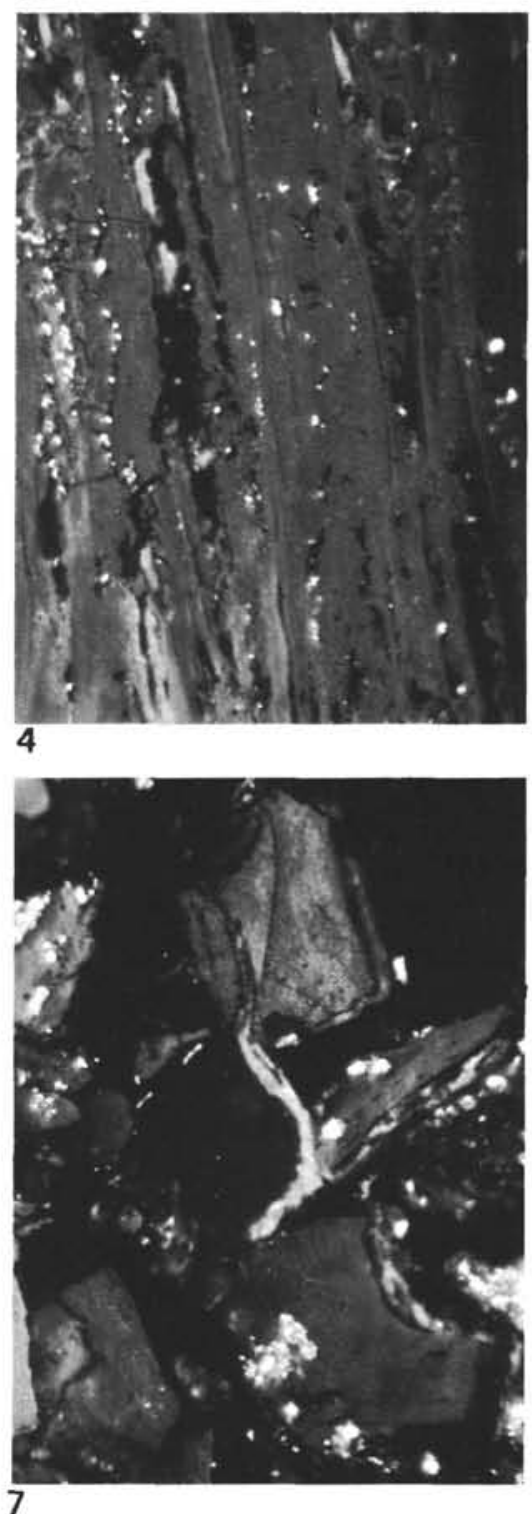